\title{
THE EFFECT OF ENTREPRENEURSHIP ORIENTATION AND MARKET ORIENTATION ON MARKETING PERFORMANCE OF FURNITURE HOME INDUSTRY IN SAWAHAN DISTRICT
}

\author{
Chatarina Felisia, Helena Sidharta, I Bagus Yosia \\ Universitas Ciputra, UC Town, Citraland, Surabaya 60219, Indonesia
}

\begin{abstract}
This study analyzes the effect of entrepreneurial orientation and market orientation on the marketing performance of furniture home industry in Sawahan District. The objectives of this research are to: (1) determine the effect of entrepreneurial orientation on marketing performance (2) determine the effect of market orientation on marketing performance. The population in this study were 158 furniture home industry businesses in Sawahan District, Surabaya. The number of samples taken is 113 respondents which was determined using the Slovin formula. By using a quantitative research approach, the sampling technique used in this study used a random sampling method. Source of data obtained in this study is through the process of distributing questionnaires to 113 respondents in the home furniture industry in the District of Sawahan. The analytical tool used was SPSS 22. The results of the research obtained are that (1) entrepreneurial orientation do not significantly influence the marketing performance of furniture home industry in Sawahan District (2) Market orientation do not significantly influence the marketing performance of furniture home industry in Sawahan District. From the results of the research, business actors can begin to implement entrepreneurial orientation and market orientation through real practice. External encouragement is needed by businesses through extension activities and intensive training given by the government to mentally equip and provide knowledge so the furniture home industry business owners in Sawahan District can maintain the sustainability of their businesses.
\end{abstract}

Keywords: market orientation, entrepreneurship orientation, marketing performance, entrepreneurship, home furniture industry

*Corresponding Author.

e-mail: helena@ciputra.ac.id 


\section{INTRODUCTION}

One of the strategic commodities for the Indonesian economy is furniture. Furniture is not only a high value-added product but also a product of global competitiveness. Based on data from the Global Business Guide Indonesia (2018), the abundance of natural resources owned by Indonesia makes the local furniture industry have a dominant contribution to the country's economy. This was reinforced by the data that in 2013 domestic furniture consumption in Indonesia reached 9 trillion Rupiahs. Even though domestic consumption is increasing, competition is also getting tougher. The competition was made more intense by the entry of foreign companies such as Informa and IKEA. For example, IKEA is a foreign furniture company that entered the Indonesian market in 2014. PT Hero Supermarket which oversees IKEA in Indonesia stated that in 2018 IKEA had a growth percentage of $21 \%$. IKEA is a modern retail company. The furniture industry with a modern style has increased, as supported by a statement by the Chairman of the Indonesian Retailers Association (Aprindo) Roy Mandey who stated that the country's retail industry is experiencing an anomaly due to a shift away from conventional forms (CNBC Indonesia, 2019). This shows a change in consumer tastes where they prefer products that offer functionality, comfort, and have a minimalist design because it allows consumers to update their home decoration regularly. This has shifted furniture preferences and consumer tastes where those who previously preferred traditional wood carving furniture have now changed due to increasingly fierce competition.

Large market opportunities in Indonesian furniture industry caused fierce competition between furniture businesses to get consumers and this had forced many parties to try to survive in the industry. One of the parties affected by the fierce competition is the suppliers of raw materials which are part of the furniture industry chain. This is reflected from the gross income data of one of the raw material supplier for furniture production in Sawahan District, namely UD Anugrah Jaya on Banyu Urip Street No. 264-266 Surabaya. Their income from 2015 to 2018 had decreased, as shown in Figure 1 below: 


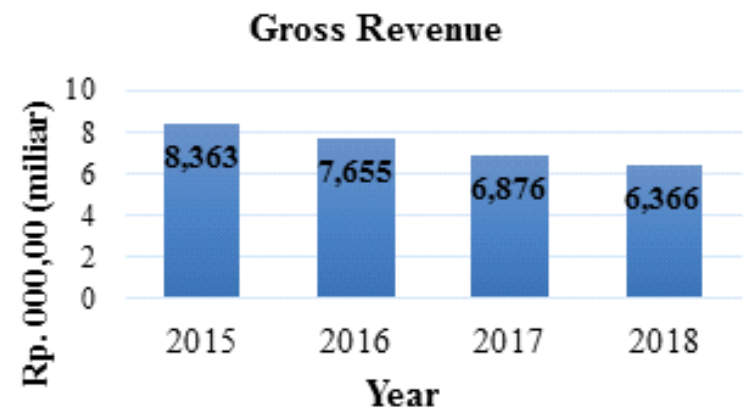

- Gross Revenue

Figure 1. UD Anugrah Jaya Gross Revenue, 2015-2018

From UD Anugrah Jaya's gross income data in 2015-2018, it can be seen that the company experienced a decrease in revenue. A similar decline had also occurred in the home furniture industry of Sawahan District. The results of interviews that have been done show that the furniture home industry businessman in Sawahan District experienced a decrease in income where there should be an opportunity to grow in their market share. It is proven by IKEA's percentage of growth in Indonesia because IKEA was able to see the opportunities in the Indonesian market. An equal opportunity should be available for the home furniture industry, especially in the district of Sawahan.

From this phenomenon, local producers, especially home furniture industry in Sawahan District, of course, must continue to maintain their market share by preparing strategies to face new competitors. Tight competition in the furniture industry will put pressure on business actors so that it can affect the company's marketing performance in implementing aligned strategies, including entrepreneurial orientation and market orientation. The purpose of this study was to first determine the effect of entrepreneurial orientation on the marketing performance of furniture home industry in Sawahan District. The second is to determine the effect of market orientation on the marketing performance of home furniture industry in the District of Sawahan. Based on the phenomena and objectives that have been described, the researcher is interested in further research on "The effect of entrepreneurial orientation and market orientation on the marketing performance of furniture home industry in Sawahan District". 


\section{LITERATURE REVIEW}

\subsection{Entrepreneurship}

According to Ramos et al., (2017), entrepreneurship is a behavior that requires individuals to take risks and overcome challenges in creating new businesses that are preceded by identifying, evaluating, and capturing opportunities. The goal to be achieved is to obtain income and generate wealth. The entrepreneurial process involves more than solving problems in a management position. The entrepreneurial process itself has several stages, namely (Leach \& Melicher, 2015: 5):

1. Formulate ideas to start a new business

2. Gathering resources

3. Managing and running the business

\subsection{Entrepreneurship Orientation}

According to Wales (2016), entrepreneurial orientation is related to personal characteristics possessed by company owners in determining a clear vision, the willingness to face challenges and risks, and the ability to create a good corporate image. Whereas according to Masa'deh et al., (2018), entrepreneurial orientation is a type of strategic orientation related to the entrepreneurial aspects of corporate strategy. Entrepreneurial orientation is a procedure, practice, and activity of corporate decision making used with the aim of increasing the value of products and services in response to customer needs so that it can lead to increased performance.

Organizations with strong entrepreneurial orientation will be more efficient in achieving a goal (Nasip et al., 2017). A business that has an entrepreneurial orientation has the ability to find and take advantage of unexploited market opportunities and to respond to challenges, and one that have the willingness to take risks when facing an uncertain condition (Mohammad et al., 2019). Indicators used to measure entrepreneurial orientation based on Masa'deh et al., (2018) consisted of:

1. Innovativeness, which is the tendency of companies to support new ideas, novelty, creativity, and experimentation that lead to the development of products, services, or technological processes in a company. 
2. Proactiveness, which is a future view in which a company tries to make new products or improve existing ones, anticipate changes and opportunities, promote changes in company tactics, and predict future market needs.

3. Risk taking, which is taking courageous actions to show commitment and uncertainty in the use of resources to achieve a goal with the risk of failure that can cause losses.

\subsection{Market Orientation}

According to $\mathrm{Na}$ et al., (2019), market orientation is the process of finding and understanding the desires of existing and potential customers, as well as observing and overcoming the activities of existing and potential competitors through the processes and activities that develop the organization and management system. Therefore, market orientation is known to make companies better in responding to market demand and predict market changes well to create sustainable competition. Meanwhile, according to Masa'deh et al. (2018), market orientation is related to the company's emphasis on creating and maintaining superior customer value. The requirement is to still pay attention to the interests of stakeholders, in addition to the provision of norms for organizational development behavior and have a responsive attitude to market information. The indicators used to measure market orientation based on Masa'deh et al. (2018) consisted of:

1. Customer orientation shows the company's superior skills in understanding and satisfying customer needs so as to create value for customers.

2. Competitor Orientation refers to the company's understanding of competitors' current and potential strengths and weaknesses as well as the competitors' long-term capabilities and strategies.

3. Interfunctional Coordination refers to the coordination of company resources so as to create value for customers.

\subsection{Marketing Performance}

According to Adesoga and James (2019), marketing performance is a marketing measurement and assessment of an organization with regard to objectives related to the market, such as revenue, growth, and market share. 
Performance shows the company's success in achieving its goals and it can be measured using goals and perceptions. Performance-based perceptions fall into two categories: perceptions of financial performance and perceptions of marketing performance. In measuring the performance of small businesses, it is more appropriate to use managers' perceptions of growth rates, because they have difficulty in gaining access to financial performance archives (Killa, 2017). Therefore, this research focuses on measuring marketing performance. The indicators used to measure perceptions of marketing performance according to Killa, (2017) include:

1. Sales Growth Perception, which reflects the perceptions of organizational owners in assessing organizational performance regarding sales compared to the industry average over the past three years. Increased sales growth reflects increased income.

2. New Customers Growth Perception, which reflects the perceptions of the organization's owners in the organization's performance regarding the growth of new customers compared to the industry average over the past three years.

3. Market Coverage Perception, which reflects the perceptions of the organization's owners in the organization's performance regarding market reach compared to the industry average over the past three years.

\subsection{Development of Hypothesis}

An entrepreneurial orientation will encourage experimentation in introducing new products or services, technological novelty in developing new processes, and the willingness to take on cost risks and challenge existing business arrangements. Risk taking and innovation as an effort to gain competitive advantage is reflected through improving marketing performance (Buli, 2017). The entrepreneurial orientation reflects the level of risk taking, proactivity, and aggressiveness of the company regarding innovation. An entrepreneurial orientation will enhance organizational transformation and renewal that can help build new competencies that drive marketing performance improvement (Masa'deh et al., 2018). The results of research conducted by Buli (2017) and Masa'deh et al. (2018) show that entrepreneurial orientation has a positive and significant effect on marketing performance. Entrepreneurial orientation as a process, practice, 
and decision-making skill that reflected in directing companies to engage in innovative, proactive, and risk-taking behavior in order to improve company performance (Aulia et al., 2019). The results of the study by Aulia et al. (2019) showed that entrepreneurial orientation did not significantly influence marketing performance. Similarly, research conducted by Hatta (2015) and Setyawati (2013) also showed that entrepreneurial orientation does not directly affect marketing performance. The differences in the results of these studies prove that this premise deserves to be analyzed. Therefore, the first hypothesis formed is: $\mathrm{H}_{1}$ : Entrepreneurial orientation $\left(\mathrm{X}_{1}\right)$ influences marketing performance $(\mathrm{Y})$.

Based on the results of research conducted by Buli (2017), market orientation can affect marketing performance in the SME industry. Market orientation is a culture contained in a business that has a role in efforts to improve marketing performance. According to Masa'deh et al. (2018) marketing performance had increased if SMEs are able to utilize the potential of adaptability and proximity to the customer base. Market orientation encourages organizational innovation which in turn will positively influence marketing performance. A business that has a high level of market orientation will have high marketing performance. A business that has a high degree of market orientation will have a competitive advantage in terms of product quality, service quality, product innovation, and cost. According to the researches conducted by Buli (2017) and Masa'deh et al. (2018), market orientation has a positive and significant effect on marketing performance. Meanwhile, according to the researches conducted by Acosta et al. (2018), Musrifah \& Murwatinigsih (2017), Hatta (2015), and Setaywati (2013), market orientation do not significantly influence marketing performance. The differences in the results of these studies prove that this premise deserves to be analyzed. So, the second hypothesis formed is: $\mathrm{H}_{2}$ : Market orientation $\left(\mathrm{X}_{2}\right)$ influences marketing performance $(\mathrm{Y})$.

Based on the proposed hypothesis, the analysis model can be described as follows: 


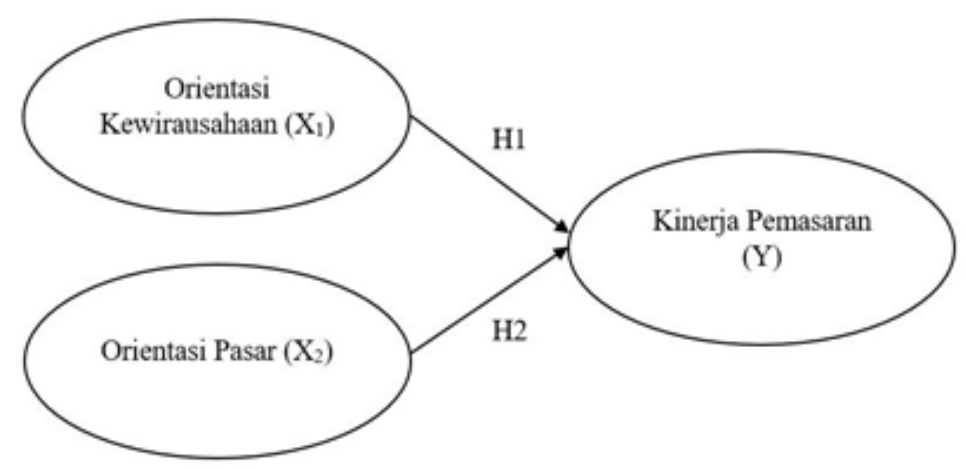

Figure 2. Analysis Model

\section{RESEARCH METHODOLOGY}

The home furniture industry in Sawahan District consists of small scale industries and in accordance with the name, the average household industry in this study has less than 10 workers or even no workers. The main aspect for sustainability of the industry is the location, which is in the home or residence of the business owner itself. The home furniture industry in Sawahan District in this study is divided into two types of businesses. The division is then divided into categories of types of business furniture and sofa upholstering. The category of furniture business according to this research are businesses that sell products ranging from cabinets, chairs, tables, and various custom-made complementary household products. While the sofa upholstering business is a type of business that focuses on repairing or relining sofas. In the upholstery category, business actors can also accept sofa orders in accordance to the wishes or demands of consumers.

The population used in this study is the consumer data from one of the suppliers of raw materials for furniture making in the district of Sawahan, namely UD Anugrah Jaya. Located in Jl. Banyu Urip No. 264, Surabaya. So that the total population to be studied is 158 furniture home industry businesses in Sawahan District, Surabaya. These businesses have been run for at least 5 years, defined thusly with the aim to assess the marketing performance of their business. This research uses probability sampling method in sampling. The sampling technique used is random sampling. In determining the sample size, this study uses the Slovin formula as a reference with an error tolerance of 0.05 . From the calculation of the Slovin formula above, the total sample used in this 
study is 113 people. The questionnaire used in this study is distributed directly to respondents. This research will use a Likert scale as a measurement of agreement from respondents, regarding their response to the research variables. The measurement scale for all indicators on each variable uses the Likert scale of 1-5 starting from Strongly Disagree (SD) to Strongly Agree (SA). The data processing obtained will be processed using SPSS version 22 .

\subsection{Results}

The total number of respondents in this study is 113 respondents who are the owners of home furniture industry in Sawahan District of Surabaya City with a minimum of 5 years of business establishment. The results of descriptive analysis that has been done shows that respondents based on business location included in the category of environmental roads occupy the highest position as many as 83 people with a percentage of $73.5 \%$. Furthermore, there are 30 business locations on the local road with a percentage of $26.5 \%$. The respondent's answer shows that the respondents in this study were dominated by the type of business that is on the environmental road. Descriptive analysis results were also conducted based on the type of business. The upholstery category occupies the most positions, as many as 58 people with the percentage of $51.3 \%$. Furthermore, the types of businesses included in the furniture category are 55 people with a percentage of $48.7 \%$. From the respondents' answers, it is seen that the respondents in this study were dominated by respondents with upholstery business type category.

Descriptive analysis results based on the long standing home furniture industry aged 11-16 years occupied the most positions with 38 people or $33.6 \%$, aged 5-10 as many as 36 people with a percentage of $31.9 \%$, aged $17-21$ years totalling 28 people with a percentage of $24.8 \%$, and over 22 years as many as 11 people with a percentage of $9.7 \%$. The answers of these respondents showed that the majority of respondents in this study have a business that has been established for 11-16 years. Based on a statement released by Ciputrauceo (2015), a company can be said to be successful if it has passed their first 5-10 years and the company is still standing or even developing and progressing. Based on Ciputrauceo, they are included in the category of success but the results are inversely proportional. From the results of interviews conducted by home 
furniture industry entrepreneurs in Sawahan District, income has decreased. Furthermore, descriptive analysis based on the length of work of respondents in the furniture industry showed that respondents who worked for 11-16 years were the most respondents in this study, as many as 33 people with a percentage of $29.2 \%$, working length of $5-10$ years as many as 30 people with a percentage of $26,5 \%$, working length of 17-21 years as many as 28 respondents with a percentage of $25.8 \%$, and the last with working length of 22 years as many as 22 respondents with a percentage of $19.5 \%$. From the answers of the respondents above, it can be understood if the respondents in this study were dominated by respondents who have worked for 11-16 years in the furniture industry. It can be concluded that business owners have sufficient experience in the furniture industry. However, in reality based on interviews with business owners they are experiencing a decline in the number of consumers.

\subsection{Validity and Reliability Test}

The results of the validity testing show that all instruments of the entrepreneurial orientation, market orientation, and marketing performance variables have a significance value of $\leqslant 0.05$. Therefore, all instruments of the statement of these variables have fulfilled the element of validity.

The results of the reliability testing show that the Cronbach's Alpha value on the entrepreneurial orientation variable is 0.853 , the market orientation variable is 0.743 , and the marketing performance variable is 0.798 , which means that the Cronbach's alpha value is $\geqslant 0.06$. So, the three variables are declared reliable.

\subsection{Normality test}

The normality test in this study uses the Kolmogorov Smirnov test. The significance value obtained is equal to 0.134 , which is greater than the required 0.05 in the normality test. So, it can be concluded that the residual regression model is normally distributed.

\subsection{Multicollinearity Test}

Multicollinearity test in this study is done by looking at the VIF value and tolerance values in the coefficients table. The VIF value of variables $X_{1}$ and $X_{2}$ 
is 1.277 while the tolerance value of the two variables is 0.783 . So, it can be concluded that there is no multicollinearity in the variables $\mathrm{X}_{1}$ and $\mathrm{X}_{2}$ because the tolerance value of the two variables is more than 0.10 while the VIF value of the two variables is less than 10 .

\subsection{Heteroscedasticity Test}

The Heteroscedacity test in this study uses the Spearman's test. The significance value of the $\mathrm{X}_{1}$ variable is 0.906 while the $\mathrm{X}_{2}$ variable is 0.563 . So, it can be concluded that there was no heteroscedasticity on these two variables because the significance value was more than 0.05 .

\subsection{Multiple Linear Regression Analysis Test}

$$
\mathrm{Y}=1,386+(-0,022) \mathrm{X}_{1}+0,308 \mathrm{X}_{2}
$$

The linear regression equation above shows that the entrepreneurial orientation regression coefficient has a negative value on the marketing performance of furniture home industry in Sawahan District. This shows that entrepreneurial orientation negatively influences their marketing performance, which in theory should have a positive effect. On the other hand, the regression coefficient of market orientation has a positive value on the marketing performance of furniture home industry in Sawahan District. This is consistent with generally accepted theories in which market orientation supports the marketing performance capabilities of an organization.

\subsection{Correlation Coefficient Analysis (R) and Determination Coefficient $\left(\mathbf{R}_{2}\right)$}

The results of testing the correlation coefficient $(\mathrm{R})$ showed a value of 0.164 which means there is a relationship between the independent variables consisting of entrepreneurial orientation $\left(\mathrm{X}_{1}\right)$ and market orientation $\left(\mathrm{X}_{2}\right)$ with the dependent variable marketing performance $(\mathrm{Y})$. The coefficient of determination $\left(\mathrm{R}_{2}\right)$ has a value of 0.027 which explains that the ability of the model to explain marketing performance $(\mathrm{Y})$ is $2.7 \%$ while the rest is explained by other factors not examined in this study. 


\section{$3.8 \mathrm{~F}$ test}

The results of the $\mathrm{F}$ test in this study showed a significance value of 0.222 , which is more than the significance value of 0.05 , so the entrepreneurial orientation variable $\left(\mathrm{X}_{1}\right)$ and market orientation $\left(\mathrm{X}_{2}\right)$ had no effect on marketing performance $(\mathrm{Y})$. These results are different from previous studies in which entrepreneurial orientation and market orientation affect marketing performance and thus forming a good research model.

\section{9 t test}

$\mathrm{T}$ test results of the entrepreneurial orientation variable $\left(\mathrm{X}_{1}\right)$ has a significance level of 0.929 , which is more than 0.05 . While the market orientation variable $\left(\mathrm{X}_{2}\right)$ has a significance level of 0.115 , which is also more than 0.05 . So, it can be concluded that the two variables entrepreneurial orientation and market orientation have no significant effect on the home furniture industry in Sawahan District.

\section{DISCUSSION}

Based on data analysis using multiple linear regression analysis, the following are the significance values of the results of the $t$ test of the entrepreneurial orientation variable $\left(\mathrm{X}_{1}\right)$ and market orientation $\left(\mathrm{X}_{2}\right)$ on Marketing Performance (Y) shown in Table 1 below.

Table 1. Significance Value of $\mathrm{t}$ Test Analysis Results

\begin{tabular}{llll}
\hline Model & & $\mathrm{t}$ & Sig. \\
& & & \\
\hline 1 & (Constant) & 3,575 & 0,001 \\
\cline { 2 - 4 } & $\mathrm{X}_{1}$ & $-0,089$ & 0,929 \\
\cline { 2 - 4 } & $\mathrm{X}_{2}$ & 1,590 & 0,115
\end{tabular}

Source: Processed data, 2019 


\subsection{The Effect of Entrepreneurship Orientation $\left(\mathrm{X}_{1}\right)$ on Marketing Performance} (Y)

Based on the results of data analysis, it can be seen that the entrepreneurial orientation variable does not partially significantly influence the marketing performance of furniture home industry in Sawahan District. In other words, $\mathrm{H}_{1}$ in this study was rejected and have no significant effect. If entrepreneurial orientation was experienced, the marketing performance did not experience the same increase in home furniture industry in Sawahan District. The results of this study support the research conducted by Aulia et al., (2019), Hatta (2015), and Setyawati (2013), which stated that entrepreneurial orientation has no significant effect on marketing performance, so it can be understood that this study can strengthen the results of previous researches. In a study conducted by Setyawati (2013), the entrepreneurial orientation variable is an antecedent of market orientation, so that it affects the outcome of the relationship that is not significant. In addition, the study also mentioned that the implementation of corporate strategy will not directly affect business performance.

The results of these studies support the results of research conducted because of the similarity of results and objects of this research are small scale businesses or MSMEs in different industrial fields. The results indicate that there is a tendency for MSMEs in Indonesia to not be able to implement an entrepreneurial orientation strategy that can directly affect marketing performance. So, it requires encouragement through variables related to marketing performance that can be through innovation, competitive advantage, and marketing capabilities. This is in line with the statement of Frank et al., (2010) which stated that entrepreneurial orientation is not a "secret weapon" in all environmental conditions and developments in a company. Frank et al., (2010) suggested that companies that have low access to financial capital can first restore the marketing performance of their business.

The insignificant result is based on the results of the descriptive analysis of the type of furniture home industry business, as the type of sofa upholstering business occupies the highest position with the number of 58 people or $51.3 \%$ of 113 respondents. Sofa upholstering business type itself is a type of business that focuses on repairing sofas. In addition to focusing on sofa repair, businesses 
also accept sofa making in accordance with consumer demand. The conclusion from the descriptive analysis of the type of furniture home industry business in Sawahan Subdistrict, the average of business actors having a sofa upholstering business type which means that business actors are more focused on workmanship on demand compared to mass product manufacturing. These results support one of the indicators that shape entrepreneurial orientation, which is innovativeness. The type of business that focuses on making products in accordance with the wishes of consumers lacks innovativeness, which is one of the indicators of entrepreneurial orientation. So, it can be concluded that it is one of the factors why entrepreneurial orientation does not affect the marketing performance of furniture home industry in the District of Sawahan.

The results of a descriptive analysis of entrepreneurial orientation variables indicate that on average the overall respondents have not implemented any entrepreneurial orientation such as risk taking, innovativeness, and proactiveness in improving marketing performance of their business. The mean total value of the entrepreneurial orientation variable is 2.14 , which means that the overall average of respondents is away from the number five response of the Likert scale category, strongly agree, in each statement of the variable. From the results of the analysis of entrepreneurial orientation variables, it can be concluded that the average overall respondents in this study have not implemented an entrepreneurial orientation strategy because furniture home industry entrepreneurs in Sawahan District do not have personal characteristics consisting of innovativeness, proactiveness, and risk taking in their business. The results of the total value of the mean marketing performance variable is 2.03 , which means that the average response of all respondents is away from the number five response on the Likert scale category, strongly agree, because the respondent's business has decreased sales growth, does not have customer growth, and market reach that has not increased over the past 3 years. From the results of data analysis, it can be concluded that the home furniture industry in Sawahan District has a low level of entrepreneurial orientation, so they have a low marketing performance. These results are also in accordance with statements made by Masa'deh et al., (2018) and Buli (2017) which stated that implementing entrepreneurial orientation in a business will help drive company performance improvement. The statement is also in accordance with the answers of the average overall furniture home 
industry businessman of Sawahan District that they have not implemented or are not aware of the importance of an entrepreneurial orientation strategy that can encourage increased marketing performance that is superior and sustainable.

\subsection{Effect of Market Orientation $\left(\mathrm{X}_{2}\right)$ on Marketing Performance ( $\mathrm{Y}$ )}

Based on the results of data analysis, it can be seen that the market orientation variable does not partially significantly influence the marketing performance of home furniture industries in Sawahan District. In other words $\mathrm{H}_{2}$ in this study was rejected and did not have significant influence. If the market orientation had increased, the marketing performance would not experience the same increase in the furniture home industry of Sawahan District.

The results of this study support the results of research conducted by Musrifah and Murwatiningsih (2017), Hatta (2015), and Setyawati (2013), which stated that market orientation does not significantly influence marketing performance, so it can be understood that this research can strengthen the results of previous researches. Not only the entrepreneurial orientation mentioned earlier but, in the research, conducted by Musrifah and Murwatiningsih (2017), Hatta (2015), and Setyawati (2013), it was also stated that the application of corporate strategy will not directly affect business performance. In order for companies to benefit from the implementation of these strategies, a driving force variable is needed so that orientation influences business marketing performance.

The results of these studies support the results of the research because of the similarity of results and objects of research conducted are on small scale businesses or commonly known as MSMEs in different industrial fields. The results indicate that there is a tendency for MSMEs in Indonesia to not be able to implement market orientation strategies that can directly affect marketing performance. So, it requires encouragement such as through innovation, competitive advantage, marketing capabilities, and various variables related to marketing performance. This is in line with the statement of Frank et al. (2010) which stated that market orientation is not a "secret weapon" in all environmental conditions and developments in a company. Frank et al. (2010) suggested that companies that have low access to financial capital can first restore the marketing performance of their business. 
This insignificant result is based on the descriptive analysis of respondents based on the business location of the furniture home industry businessman in Sawahan Subdistrict, which based on business location in the category of environmental road occupies the highest position with 83 people or $26.5 \%$ of 113 respondents. The existence of a business location is one important factor in running a business. The average business location of all respondents is in the category of environmental roads or based on the division of these categories is that as many as 83 people are not on the main road. This makes their business less known by the wider community. Locations that are difficult to reach and not easily accessible to consumers will certainly affect customer satisfaction in the transaction. Customer satisfaction, which is one of the statements from the establishment of customer orientation indicators, is not of more concern to the furniture home industry businessman in Sawahan District. This is evidenced from the results of an interview with one of the suppliers of raw materials from furniture home industry businesspeople in the District of Sawahan. The owner of the supplier of raw materials, Mr. Wukirno, stated that fraud often occurs and is carried out by furniture home industry businesses in Sawahan District, ranging from asking for blank notes, asking to increase the price of goods to changing product quality that is not in accordance with the order. This is done by business owners because they want more profit without any regard to the long-term effects on the satisfaction of their customers. By not paying attention to customer satisfaction in meeting customer needs, then the businesses do not implement customer orientation, which is one of the indicators that shape market orientation. From the results of this analysis it can be concluded that this has become one of the market orientation factors that does not affect the marketing performance of furniture home industry in the District of Sawahan.

The results of the descriptive analysis of entrepreneurial orientation variables indicate that the average overall respondent has not yet implemented a market orientation strategy consisting of customer orientation, competitor orientation, and interfunctional coordination in improving marketing performance in their business. The results of descriptive analysis as a whole when looking at the total mean value of the market orientation variable is only 2.26 , which means that the average overall respondents is away from the number five response from 
the Likert scale category that states strongly agree with the statement of these variables because the average overall respondents have not applied this market orientation strategy. which is caused by the furniture home industry business players in Sawahan District not yet discovering and understanding the desires of their customers so as to create superior value for customers who ultimately cannot support superior and sustainable marketing performance. While the total mean value of marketing performance variable is 2.03 , which means that the average overall respondents is away from the number five response of the Likert scale category that states strongly agrees with the statement of these variables because the business of respondents has decreased sales growth, no customer growth, and market reach has not increased in the past three years. The results are also in accordance with the statement given by Buli (2017), Acosta et al. (2018), and Masa'deh et al. (2018) which stated that a business that has a high level of market orientation will have a high marketing performance. The statement is in accordance with the answers that state that the average overall furniture home industry businessmen of Sawahan District have not implemented or are not aware of the importance of applying market orientation strategies that can encourage increased marketing performance that is superior and sustainable.

\section{CONCLUSION}

Based on the results and discussion of the research that has been done, it can be concluded that the entrepreneurial orientation variable does not significantly influence the marketing performance of furniture home industry in Sawahan District, so that the first Hypothesis $\left(\mathrm{H}_{1}\right)$ is rejected. That is, if the entrepreneurial orientation increases, marketing performance does not experience the same increase in the home furniture industry in Sawahan District. The results of the study of market orientation variables $\left(\mathrm{X}_{2}\right)$ also did not significantly influence the marketing performance of furniture home industry in the District of Sawahan, so that the second Hypothesis $\left(\mathrm{H}_{2}\right)$ was rejected. That is, if the market orientation has increased, the marketing performance does not experience the same increase in the home furniture industry in the District of Sawahan. 


\subsection{Suggestions}

It is suggested for home furniture industry in Sawahan District to consider implementing entrepreneurial and market orientation in their business. Because having a high level of entrepreneurial orientation and market orientation can help drive the marketing performance of furniture home industry in Sawahan District.

Based on the results of research conducted, it can be suggested for government and private institutions to provide training in accordance with the needs of these businesspeople, especially the owners of home furniture industry in the District of Sawahan. The training is expected to be implemented through real practice to improve the marketing performance of business actors in order to maintain the sustainability of their businesses.

It is suggested to further researches in similar topics to be able to consider examining variables that have an influence on marketing performance. For example, using the innovation variable, competitive advantage, or marketing capability as an intervening variable. The use of two measures of marketing performance subjectively and objectively will assist the development of further researches. Future researches can use the interview method of data collection. Data collection by interview is expected to be able to get more specific and clear results from the respondents. Future studies can choose research objects that come from other categories of home industry.

\subsection{Research Limitations}

This research has been carried out in accordance with scientific procedures, but nevertheless has limitations. The limitation of this research lies in the longterm search of respondents' data because the researchers have to wait for respondents to make a transaction at UD Anugrah Jaya or they must contact the respondents to be willing to fill out the questionnaire. Another limitation in this study is the statements of the questionnaire, where there are some statements that may not be understood easily by respondents. So, there is a possibility that the answer is not in accordance to the actual situation. 
Chatarina Felisia, Helena Sidharta, I Bagus Yosia / The Effect of Entrepreneurship Orientation and Market Orientation on Marketing Performance of Furniture Home Industry in Sawahan District

Appendix A. Measurement of the mean and standard deviation

\begin{tabular}{|c|c|c|c|}
\hline No. & Statement & Mean & $\begin{array}{c}\text { Std. } \\
\text { Deviation }\end{array}$ \\
\hline \multicolumn{4}{|c|}{ Entrepreneurship Orientation $\left(\mathrm{X}_{1}\right)$} \\
\hline 1 & In my business, new ideas emerge all the time & 2,14 & 0,789 \\
\hline 2 & Continuous renewal and innovation are important for my business & 2,31 & 0,846 \\
\hline 3 & Lately I have launched many new products/services & 2,29 & 0,932 \\
\hline 4 & $\begin{array}{l}\text { I invest in developing new products, services and business } \\
\text { practices }\end{array}$ & 2,36 & 0,877 \\
\hline 5 & In my business, I often act first before competitors do it & 2,13 & 0,807 \\
\hline 6 & $\begin{array}{l}\text { I have a goal to be at the forefront of development in the furniture } \\
\text { industry sector }\end{array}$ & 1,84 & 0,689 \\
\hline 7 & I prefer to be careful even though some opportunities will be lost & 2,26 & 0,843 \\
\hline 8 & In achieving my business goals, courageous action is needed & 1,86 & 0,778 \\
\hline 9 & In an uncertain situation I am not afraid to take big risks & 2,07 & 0,664 \\
\hline \multicolumn{2}{|r|}{ Total Mean } & 2,14 & \\
\hline \multicolumn{4}{|c|}{ Market Orientation $\left(\mathrm{X}_{2}\right)$} \\
\hline 1 & $\begin{array}{l}\text { I continue to monitor the level of commitment and orientation to } \\
\text { serve customer needs }\end{array}$ & 2,30 & 0,693 \\
\hline 2 & My business goals are driven by customer satisfaction & 2,65 & 0,755 \\
\hline 3 & $\begin{array}{l}\text { My business goals are driven by the creation of greater customer } \\
\text { value }\end{array}$ & 2,37 & 0,710 \\
\hline 4 & $\begin{array}{l}\text { My competitive strategy is based on my strategy in understanding } \\
\text { customer needs }\end{array}$ & 2,68 & 0,816 \\
\hline 5 & I often measure customer satisfaction & 2,37 & 0,908 \\
\hline 6 & I pay attention to service and service after purchase & 2,38 & 0,686 \\
\hline 7 & $\begin{array}{l}\text { My sales representative regularly shares information about } \\
\text { competitors' activities }\end{array}$ & 2,07 & 0,637 \\
\hline 8 & I quickly respond to competitive actions that threaten my business & 2,04 & 0,801 \\
\hline 9 & $\begin{array}{l}\text { My fellow workers and I regularly discuss competitor strengths } \\
\text { and actions that must be taken }\end{array}$ & 2,35 & 0,767 \\
\hline 10 & $\begin{array}{l}\text { I target customers where I have the opportunity to achieve } \\
\text { competitive advantage }\end{array}$ & 2,42 & 0,741 \\
\hline 11 & I regularly visit my business customers and prospect customers & 2,15 & 0,804 \\
\hline 12 & $\begin{array}{l}\text { I freely communicate information about my successful and } \\
\text { unsuccessful customer experiences in all business functions }\end{array}$ & 1,96 & 0,737 \\
\hline 13 & $\begin{array}{l}\text { All of my business functions are integrated in serving the needs of } \\
\text { my target market. }\end{array}$ & 2,02 & 0,767 \\
\hline 14 & $\begin{array}{l}\text { I understand how everyone in my business can contribute to } \\
\text { creating customer value. }\end{array}$ & 1,96 & 0,712 \\
\hline 15 & I share resources with other business functions & 2,19 & 0,620 \\
\hline \multirow{2}{*}{\multicolumn{4}{|c|}{ Marketing Performance (Y) }} \\
\hline & & & \\
\hline 1 & My business has increased sales growth over the past 3 years & 2,14 & 0,895 \\
\hline 2 & My business has had new customer growth for the past 3 years & 2,12 & 0,721 \\
\hline \multirow{2}{*}{\multicolumn{2}{|c|}{\begin{tabular}{r|r}
3 & My business has increased market reach over the past 3 years \\
Total Mean
\end{tabular}}} & 1,84 & 0,751 \\
\hline & & 2,033 & \\
\hline
\end{tabular}




\section{REFERENCE}

Acosta, A. S., Crespo, A. H., \& Agudo, J. C. (2018). Effect of market orientation, network capability and entrepreneurial orientation on international performance of small and medium enterprises (SMEs). International Business Review, Vol. 30, pp. 1-13.

Adesoga, A., \& James, A. (2019). Channel strategy and marketing performance of selected consumer goods firms in Lagos State, Nigeria. Academy of Marketing Studies Journal, Vol. 23, No. 1, pp. 1-18.

Aulia, R., Astuti, M., \& Ridwan, H. (2019). Meningkatkan kinerja pemasaran melalui orientasi pasar dan orientasi kewirausahaan. Jurnal Ilmiah Manajemen Dan Bisnis, Vol. 20, No. 1. Pp. 27-38.

Buli, B. M. (2017). Entrepreneurial orientation, market orientation and performance of SMEs in the manufacturing industry: Evidence from Ethiopian enterprises. Management Research Review, Vol. 40, No. 3, pp. 292-309.

Cnbc Indonesia. (2019). Merugi di Q3, Hero Ekspansi 2 Gerai IKEA Tahun Depan. Retrieved on January 01, 2020 from https://www.cnbcindonesia.com/ market/20191129175127-17-119181/merugi-di-q3-hero-ekspansi-2-geraiikea-tahun-depan

Frank, H., Kessler, A., \& Fink, M. (2010). Entrepreneurial Orientation and Business.

Performance - A Replication Study. Schmalenbach Business Review, Vol. 62, No. 2, pp. 175-198.

Global Business Guide Indonesia. (2018). Indonesia's Furniture Industry: Competitive Advantages Hampered by Bureaucracy. Retrieved on September 17, 2019 from http://www.gbgindonesia.com/en/manufacturing/article/2018/ indonesia_s_furniture_industry_competitive_advantages_hampered_by_bureaucracy_ 11859.php

Killa, M. F. (2017). A Study on Product Innovation Portfolio and Customer Value Creation/: Bridging Entrepreneurial Risk-Taking Orientation and Marketing Performance. ASEAN Marketing Journal, Vol. 9, No. 2, pp. 80-89.

Leach, J., \& Melicher, R. (2015). Entrepreneurial Financel : 5th Editon. Stamford: Cengage Learning. 
Masa'deh, R., Al-Henzab, J., Tarhini, A., \& Obeidat, B. Y. (2018). The associations among market orientation, technology orientation, entrepreneurial orientation and organizational performance. Benchmarking, Vol. 25, No. 8 , pp. 3117-3142.

Mohammad, I. N., Massie, J. D. D., \& Tumewu, F. J. (2019). The Effect Of Entrepreneurial Orientation And Innovation Capability Towards Firm Performance In Small And Medium Enterprises (Case Study: Grilled Restaurants In Manado). Jurnal EMBA, Vol. 7, No. 1, pp. 1-10.

Musrifah., \& Murwatiningsih. (2017). Pengaruh orientasi pasar dan kewirausahaan terhadap kinerja pemasaran melalui keunggulan bersaing. Management Analysis Journal. Vol. 6, No. 4, pp. 495-505.

Na, Y. K., Kang, S., \& Jeong, H. Y. (2019). The effect of market orientation on performance of sharing economy business: Focusing on marketing innovation and sustainable competitive advantage. Sustainability (Switzerland), Vol. 11, No. 3.

Nasip, S., Fabeil, N. F., Buncha, M. R., Nga, J., Hui, L., Laison, S., \& Jr, S. (2017). The Influence Of Entrepreneurial Orientation And Social Capital On The Business Performance Among Women Entrepreneurs Along West Coast Sabah. Proceedings of International Conference on Economics 2017, 2017(Ice), pp. 377-395.

PT. Hero Supermarket. Tbk. (2018). Paparan Publik Tahun 2018. Retrived on June 3, 2019 from https://www.hero.co.id/media/detail/856

Ramos-González, M. del M., Rubio-Andrés, M., \& Sastre-Castillo, M. Á. (2017). Building corporate reputation through sustainable entrepreneurship: The mediating effect of ethical behavior. Sustainability (Switzerland), Vol. 9, No. 9.

Setyawati, H. A. (2013). Pengaruh Orientasi Kewirausahaan dan Orientasi Pasar Terhadap Kinerja Perusahaan Melalui Keunggulan Bersaing dan Persepsi Ketidakpastian Lingkungan sebagai Prediksi Variabel Moderasi. Jurnal Fokus Bisnis, Vol. 12, No. 2, pp.20-32.

Wales, W. J. (2016). Entrepreneurial orientation: A review and synthesis of promising research directions. International Small Business Journal: Researching Entrepreneurship, Vol. 34, No. 1, pp. 3-15. 
Review of Management and Entrepreneurship

Volume 04, Number 02, October 2020 